\title{
PERANCANGAN KURIKULUM SEKOLAH MENENGAH KEJURUAN SEBAGAI PRANATA BUDAYA KERJA
}

\section{VOCATIONAL SCHOOL CURRICULUM DESIGN AS A WORK CULTURAL INSTITUTION}

\author{
Sutjipto \\ Pusat Kurikulum dan Pembelajaran, Balitbang, Kemdikbud \\ Jl. Gunung Sahari Raya, Nomor 4A, Jakarta Pusat \\ E-mail: sutjipto.55@gmail.com
}

Naskah diterima tanggal: 28-02-2019 disetujui tanggal: 18-04-2019

\begin{abstract}
This study is to describe comprehensively the design of vocational high school curriculum as a work culture institution. The results of the study five things. First, the important content of work culture values for vocational school students. Second, curriculum developers are encouraged to modify the work culture, which leads to the values of hard work, work ethic, discipline, responsibility, creativity, cooperation, morality, to ethical and aesthetic standards. Third, curriculum developers are encouraged to redefine the essence of industrial work practices carried out by students. Fourth, the growth of work culture in schools is designed with shared commitment through systems, structures, regulations, and daily practices. Fifth, strengthening the work culture can be implemented in two ways, namely internalizing the values of work culture and creating a friendly school environment with a work culture. Study it conclude that the design of the vocational high school curriculum must generate students with capability in transforming moral and performance-based work culture institutions.
\end{abstract}

Keywords: curriculum design, work culture, vocational school

\begin{abstract}
Abstrak: Tujuan dari kajian ini adalah untuk mendeskripsikan secara komprehensif perancangan kurikulum sekolah menengah kejuruan sebagai pranata budaya kerja. Hasil pengkajian terkait dengan perancangan kurikulum sekolah menengah kejuruan, diperoleh lima hal. Pertama, muatan nilai-nilai budaya kerja bagi peserta didik sekolah menengah kejuruan penting. Kedua, pengembang kurikulum didorong untuk mengoreksi kembali pranata budaya kerja, yang mengarah pada nilai-nilai kerja keras, etos kerja, disiplin, tanggung jawab, kreativitas, kerja sama, moralitas, hingga standar etika dan estetika. Ketiga, pengembang kurikulum didorong untuk merumuskan ulang secara jelas esensi dari praktik kerja industri yang dilakukan peserta didik. Keempat, penumbuhan budaya kerja di sekolah dirancang dengan komitmen bersama melalui sistem, struktur, peraturan, dan praktik keseharian. Kelima, untuk penguatan budaya kerja bisa dilakukan melalui dua strategi, yaitu internalisasi nilai-nilai budaya kerja dan penciptaan lingkungan sekolah yang ramah dengan budaya kerja. Dari hasil kajian dapat disimpulkan bahwa perancangan kurikulum sekolah menengah kejuruan harus membawa peserta didik mampu mentransformasikan pranata budaya kerja berbasis moral dan kinerja.
\end{abstract}

Kata kunci: perancangan kurikulum, budaya kerja, SMK 


\section{PENDAHULUAN}

Daya saing bangsa dan tantangan dalam persaingan masyarakat global perlu ditingkatkan. Oleh karena itu pendidikan kejuruan di Indonesia, khususnya sekolah menengah kejuruan (SMK) perlu dibenahi secara tersistem dan menyeluruh. Hal ini dilakukan untuk menjadikan lulusan siap pakai sesuai kebutuhan pasar kerja dan memiliki keunggulan kompetitif yang berbeda ( $\mathrm{Ha}-$ Brookshire \& Lee, 2010). Sebagai respon dari isu tersebut, terbit Instruksi Presiden Republik Indonesia Nomor 9 Tahun 2016 tentang Revitalisasi SMK dalam Rangka Peningkatan Kualitas dan Daya Saing Sumber Daya Manusia Indonesia (Republik Indonesia, 2016). Semangat yang diemban dari Inpres tersebut memberi makna bahwa keberadaan SMK bukan hanya penting, melainkan cukup strategis dalam rangka menyiapkan lulusan yang kompeten dan siap bekerja dalam kerangka pembangunan ekonomi.

Di beberapa negara maju, seperti Amerika Serikat, Jerman, Austria, Swiss, Denmark, dan Korea Selatan mempunyai perhatian yang sangat serius dalam membuat kebijakan untuk mengawal tumbuhkembangnya pendidikan kejuruan. Kebijakan tersebut umumnya didorong keinginan bahwa pertumbuhan ekonomi suatu negara salah satunya adalah adanya sistem pendidikan kejuruan yang kuat. Saat ini, di Jerman ada sekitar 1,4 juta tenaga magang yang menyerap berbagai pengetahuan kerja pada 327 profesi (Kompas, 2017). Bahkan, di negara tersebut pendidikan kejuruan dan ekonomi diibaratkan bagai dua sisi sebuah koin logam yang saling berkaitan. Pendidikan kejuruan diperlukan karena memiliki paradigma yang menekankan pada permintaan pasar (demand driven) guna mendukung pembangunan ekonomi.

Keberadaan SMK diharapkan mampu menjawab dua isu strategis, yaitu sebagai penghasil tenaga kerja terampil yang berpengaruh pada penyerapan tenaga kerja dan pertumbuhan ekonomi serta dibutuhkan kalangan dunia usaha dan dunia industri (DUDI) (Hiniker \& Putnam, 2009; King \& Palmer, 2010; Sonhadji, 2012). Berpijak pada kebutuhan DUDI yang selama ini masih bermasalah, penting menata kembali berbagai faktor yang memengaruhi lulusan. Dua hal yang perlu dipertimbangkan dalam menata ulang SMK. Pertama, penataan pada pemangku kepentingan yang paling memerlukan, yaitu bagaimana menguatkan kecakapan, keterampilan, kompetensi, dan budaya kerja peserta didik. Kedua, penataan pada dokumen kurikulum pendidikan SMK yang sarat dengan muatan untuk membekali mereka kecakapan, keterampilan, kompetensi, dan budaya kerja sehingga menghasilkan kualifikasi lulusan yang siap bekerja.

Kurikulum SMK yang sarat dengan muatan kecakapan, keterampilan, kompetensi, dan budaya kerja yang mengikuti perkembangan kebutuhan tenaga kerja yang niscaya dikembangkan di tengah kompetisi yang sangat ketat. Dalam konteks ini, Tran (2013) memberi penjelasan bahwa kualifikasi pendidikan kejuruan di Australia dirancang untuk memberi peserta didik keterampilan, pengetahuan, dan atribut yang dibutuhkan di tempat kerja. Paket pelatihan berbasis kompetensi merupakan hal yang diwajibkan bagi peserta didik yang mengikuti program pendidikan dan pelatihan kejuruan atau Vocational Education and Trainig (VET) Australia. Hasil kajian ini menegaskan bahwa kompetensi yang sebenarnya itulah yang akan mengantarkan lulusan SMK siap bekerja sehingga mengantarkan mereka pada kehidupan yang lebih baik dan sejahtera.

Sekolah kejuruan berbasis kompetensi menurut Newton dan Kirk (1999) menerapkan program pembelajaran eksperimental dalam mendorong hubungan antara teori dan praktik. Hal tersebut untuk mendorong peserta didik senantiasa mengembangkan dan memperbarui pengetahuan mereka secara terus-menerus. Sekolah kejuruan seperti itu, umumnya 
menggabungkan kurikulum pendidikan sekolah dan praktik langsung di DUDI. Sekolah kejuruan yang memadukan penguasaan pengetahuan teknis di sekolah dan kompetensi praktis dengan DUDI membuat peserta didik mampu memiliki kecakapan persyaratan kerja, budaya kerja, mampu merencanakan, melaksanakan, dan mengontrol proses-proses kerja yang kompleks dalam profesi yang akan dijalani kelak.

Model pendidikan seperti ini akan mengantarkan lulusan SMK langsung siap bekerja sesuai kebutuhan DUDI karena mereka memiliki kemampuan yang disebut kompetensi bertindak. Ruang lingkup kompetensi tersebut merupakan hasil identifikasi dari konsep analisis empiris proses kerja atau tugas terhadap kompetensi yang dibutuhkan sebagai dasar kurikulum (Bauer \& Przygodda, 2003). Kompetensi yang dibutuhkan akan terlaksana secara efektif dan efisien jika kerja sama antara lembaga pendidikan tersebut dengan DUDI dapat terjalin secara tepat guna dan berkelanjutan. Dalam banyak aspek, kerja sama antara SMK dan DUDI menjadi hal yang fundamental. Keberhasilan penyelenggaraan pendidikan kejuruan di Jerman misalnya, karena adanya Joint Goverment dan Industry Program. Pemerintah Federal dan pemilik DUDI saling berbagi dalam kemasan budaya kerja yang merupakan persyaratan implementasi kurikulum sekolah kejuruan yang sekaligus menjadi persyaratan calon pekerja.

Pada saat bersamaan, persyaratan kerja di kalangan DUDI terus mengalami perubahan. Terdapat beberapa kekuatan yang mengubahnya, antara lain perkembangan teknologi informasi dan komunikasi (TIK) yang sangat pesat; munculnya ragam jenis pekerjaan baru seiring dengan perkembangan sains dan teknologi; berbagai karakter produksi, jasa, konstruksi, dan pola kerja yang terus berubah; ragam kebutuhan kecakapan yang multivarian; hingga respons terhadap dampak lingkungan dan perubahan iklim. Karena itu, wajar apabila ukuran DUDI dalam melihat kualifikasi tenaga kerja
Iulusan SMK adalah dengan memperhatikan kompetensi dan tingkat produktivitas kerjanya. Kompetensi dan produktivitas kerja erat hubungannya dengan seberapa baik pengetahuan, kecakapan, keterampilan, kemampuan, sikap, dan budaya kerja yang dimiliki pekerja.

Sementara itu, pada aspek pengetahuan, kecakapan, keterampilan, kemampuan, sikap, dan budaya kerja yang dimiliki lulusan SMK secara individual masih memiliki persoalan. Salah satu indikatornya adalah bahwa lulusan SMK masih tercatat sebagai penyumbang terbesar angka pengangguran. Data dari Badan Pusat Statistik (BPS) tentang angkatan kerja pada Februari 2017 sebanyak 131,55 juta orang, Tingkat Pengangguran Terbuka (TPT) SMK mencapai 1,35 juta orang atau 9,27\%, lebih tingggi dari pada lulusan SMA dan SMP. Hal ini menunjukkan bahwa mereka masih memiliki persoalan kecakapan dengan kebutuhan DUDI. Bahkan dalam Berita Resmi Statistik BPS 5 Mei 2017, angka tersebut dinyatakan paling tinggi di antara tingkat pendidikan lain. Kondisi tersebut diprediksi bukan makin menurun, bahkan makin meninggi. Harian Kompas edisi 14 November 2017 menurunkan tulisan pada halaman 17 "Lulusan Vokasi Menganggur" karena Kurikulum Tak Sesuai dengan Kebutuhan Industri. Dampaknya, sekitar 11,41 persen pengangguran terbuka pada Agustus 2017 dari lulusan SMK.

Fakta empiris lainnya, kesenjangan lulusan SMK masih terjadi antara jumlah lulusan dan kebutuhan DUDI. Lulusan SMK bidang kelautan dan perikanan tahun 2016, misalnya, hanya 17.249 orang, sedangkan kebutuhan tenaga kerja untuk bidang tersebut mencapai 3.364.297 orang. Kesenjangan Iulusan SMK juga terlihat di bidang agribisnis dan agroteknologi. Berdasarkan Data Pokok Pendidikan (Dapodik) Oktober 2016, kebutuhan tenaga kerja tingkat pendidikan menengah di bidang tersebut sebanyak 445.792 orang, sedangkan lulusan SMK yang tersedia hanya 52.319 orang. Peluang 
kebutuhan tenaga kerja di bidang pariwisata tercatat 707.600 orang, namun pada 2016 jumlah lulusan SMK di bidang ini hanya 82.171 orang. Sebaliknya, jumlah lulusan SMK di bidang bisnis dan manajemen terlalu berlebih yaitu 348.954 orang, sedangkan peluang kebutuhan tenaga kerja bagi bidang ini hanya 119.255 orang (Kementerian Pendidikan dan Kebudayaan, 2016)

Pada Kurikulum 2013 SMK pembidangan program yang dapat dilaksanakan oleh sekolah sebenarnya cukup lengkap dan ragam. Pada kurikulum 2013, program kurikulum SMK menawarkan sembilan bidang keahlian, yakni: 1) teknologi dan rekayasa, 2) energi dan pertambangan, 3) teknologi informasi dan komunikasi, 4) kesehatan dan pekerjaan sosial, 5) agribisnis dan agroteknologi, 6) kemaritiman, 7) bisnis dan manajemen, 8) pariwisata, dan 9) seni dan industri kreatif. Kesembilan bidang keahlian tersebut mewadahi 142 kompetensi keahlian dengan program belajar selama 3 tahun dan 4 tahun (Kementerian Pendidikan dan Kebudayaan, 2018). Dengan cakupan pembidangan seperti itu, dapat dikatakan bahwa hampir semua prediksi kebutuhan tenaga kerja DUDI dapat diisi lulusan. Artinya, lulusan dari SMK dapat menyuplai tenaga kerja terampil dalam cakupan kebutuhan yang sangat luas.

Realita yang terjadi bahwa tenaga kerja lulusan SMK belum mampu terserap secara optimal oleh DUDI. Adanya tingkat pengangguran terbuka lulusan SMK mencapai $9,27 \%$, adanya bidang agribisnis dan agroteknologi meluluskan 52.319 orang dari kebutuhan 445.792 orang. Lulusan bidang pariwisata 82.171 orang dari kebutuhan 707.600 orang. Salah satu faktor yang menyebabkan hal ini adalah kualitas lulusan SMK belum memenuhi kualifikasi yang dibutuhkan oleh DUDI (Ngadi, 2014; Ningsih, 2016).

Berbagai aspek kualifikasi lulusan, seperti sikap, kecakapan, keterampilan, kompetensi, dan budaya kerja, yang menciptakan makna pada penyiapan tenaga kerja belum selaras dengan kebutuhan dan harapan DUDI. Hal ini dikuatkan oleh Widarto, Sukir, Purnastuti, dan Wagiran (2007) dalam kajiannya menyebutkan bahwa terdapat beberapa kelemahan Iulusan SMK dalam memasuki dunia kerja, yakni terkait dengan aspek soft skills seperti rasa percaya diri, kemampuan adaptasi, komunikasi, disiplin, etos kerja, hingga kemampuan kerja sama.

Berdasarkan latar belakang di atas, dapat dirumuskan sebuah permasalahan, yakni: budaya kerja seperti apa yang dapat dirancangkan ke dalam kurikulum SMK sehingga berfungsi sebagai pranata yang mampu menjembatani antara penyiapan tenaga kerja dan kebutuhan DUDI? Tujuan dari kajian ini adalah ingin mendeskripsikan secara komprehensif rancangan kurikulum SMK sebagai pranata budaya kerja. Kerangka pikir tujuan yang dikonstruk tersebut juga merujuk pada pandangan Berbiglia (2011) bahwa tujuan spesifiknya adalah untuk menggambarkan rancangan yang sesuai dengan kerangka konseptual kurikulum.

\section{PEMBAHASAN}

Pendeskripsian terhadap perancangan kurikulum kejuruan sebagai pranata budaya kerja peserta didik SMK akan ditinjau dari empat perspektif, yaitu: 1) muatan kurikulum SMK, 2) kerangka konseptual budaya kerja, 3) penginternalisasian budaya kerja, dan 4) tanggung jawab sekolah. Dengan demikian, pokok kajian dibatasi pada keempat dimensi.

\section{Bagaimana Seyogianya Muatan Kurikulum SMK?}

Salah satu permasalahan yang krusial dalam kajian kebijakan SMK dari waktu ke waktu adalah penetapan tujuan dalam kurikulum tersebut. Tujuan kurikulum SMK diharapkan senantiasa selaras secara simbiosis dengan kebutuhan DUDI. Banyak hal yang harus diselaraskan, bukan hanya sebagai instrumen kebijakan negara, melainkan juga keterampilan, 
kompetensi, pemahaman, kecerdasan, kecakapan, pengertian, perilaku, sikap, budaya kerja, dan apresiasi di tempat kerja. Atchoarena (2009) menyatakan bahwa kurikulum sekolah kejuruan dikembangkan tidak hanya menjadi kebijakan pemerintah, tetapi juga menggunakan instrumen kebijakan sosial, ekonomi, politik, dan ketenagakerjaan. Dua konteks tersebut memberi penegasan bahwa SMK utamanya menyiapkan tenaga kerja bagi bidang pekerjaan tertentu di masa depan. Sebagai penyiapan tenaga kerja, maka perancangan muatan kurikulum SMK seyogianya dikembangkan bersama dengan pihak penggunanya, yaitu DUDI.

Pada saat pendidikan kejuruan lulusannya diarahkan untuk siap bekerja di DUDI, maka strategi pembelajarannya yang terhubung langsung dengan dunia kerja. Keterhubungan atau kemitraan antara sekolah dengan DUDI hendaknya dibangun atas dasar saling menguntungkan dan harus menjadi bagian dari pelatihan bekerja serta pembentukan budaya kerja. DUDI dengan kelengkapan sumber daya mampu menyediakan fasilitas, instruktur, serta sarana dan prasarana untuk praktik kerja bagi peserta didik dan pemagangan guru. Pada sisi yang lain, juga harus ada upaya kebijakan, baik dari pemerintah maupun pemerintah daerah, misalnya menyediakan insentif fiskal bagi DUDI yang membina dan mengembangkan SMK. Rancangan kurikulum pada model seperti ini dapat dimaknai sebagai menggunakan pendekatan keterhubungan dan kesepadanan (link and match) dengan permintaan kecakapan dan budaya kerja di DUDI.

Di banyak negara, pendekatan implementasi kurikulum pendidikan kejuruan secara dual dengan DUDI merupakan sebuah keniscayaan. Hal ini sekaligus memberi sinyal kuat akan keberhasilan di bidang pendidikan kejuruan apabila didukung oleh sekolah yang implementasi kurikulumnya terhubung langsung (bermitra) dengan DUDI. Premis tersebut selaras dengan Gondo dan Dafuleya (2010) dalam kajiannya tentang program pendidikan kejuruan dan pelatihan teknis (Technical Vocational Education and Training for Micro-Enterprise Development in Ethiopia: A Solution or Part of the Problem?/TVET) yang terjadi di Ethiopia, bahwa promosi usaha mikro dan kecil menjadi pusat pengembangan dan perluasan pusat TVET di seluruh negeri. Hubungan yang ada antara TVET dan usaha mikro tidak hanya sebagai salah satu kapasitas, penggunaan, dan transformasi yang terkendali, tetapi juga merupakan pendekatan yang saling menguntungkan pada perluasan dan pengembangan institusi TVET di seluruh negeri.

Dengan perluasan dan pengembangan SMK, peserta didik di sekolah tersebut setiap hari selalu melibatkan diri dengan pekerjaan secara nyata. Sehingga lambat laun dan pasti akan terjadi transformasi budaya, baik keterampilan kerja, kecakapan kerja maupun budaya kerja. Joo (2007) dalam makalahnya berkait dengan bagaimana mobil sebagai bagian penting dari budaya Amerika, mengubah budaya dan masyarakat Amerika. Karakteristik pekerjaan produk (mobil) dari hasil teknologi tertentu membantu menguatkan transformasi budaya, mampu mengubah budaya dan masyarakat Amerika. Hal ini selaras dengan salah satu hasil kajian Bendassolli (2016) bahwa pekerjaan adalah kegiatan yang dimediasi oleh tanda yang terjadi melalui budaya.

Banyak negara yang berhasil membuat kebijakan pendidikan kejuruan karena didukung kemitraan antara lembaga pendidikan dengan DUDI. Misalnya, negara Finlandia menurut Aaltonen, Isacsson, Laukia, dan VanhanenNuutinen (2013) dengan jelas menyebutkan pentingnya relasi antara sekolah dengan perguruan tinggi dan industri dalam mencapai tujuan pendidikan kejuruan yang baik. Bagi Aaltonen, sangat tidak mungkin memisahkan ketiga institusi itu ketika sebuah kebijakan pendidikan kejuruan ingin dikembangkan oleh sebuah negara. Pendekatan ini dapat dimaknai 
bahwa kemitraan yang sinergis antara sekolah dengan DUDI dan perguruan tinggi menjadi modal awal dalam mengembangkan budaya kerja. Pola itu, setidaknya akan memberikan arah yang jelas pada muatan kurikulum beserta pembelajaran di SMK bagi pengembangan kecakapan kerja, kinerja, etos kerja, dan budaya kerja yang sejalan dengan kondisi dan kebutuhan DUDI.

Muatan kurikulum yang dirancang untuk SMK bagi peserta didik yang diarahkan menjadi tenaga kerja akan mendapat kebermaknaan kompetensi dan budaya kerja karena pembelajaran mereka terlibat langsung dengan budaya kerja yang ada di DUDI. Model pembelajaran bisa mengantarkan mereka untuk siap bekerja dan terasah produktivitasnya, kreativitasnya, keinovatifannya, penguatan sikapnya, keterampilannya, dan pengetahuan yang terintegrasi dengan budaya kerja. Pembelajaran tersebut menjadi lebih bermakna, Slamet (2011) berpendapat bagaimana menyediakan lulusan (supply) yang terkait dan sepadan dengan permintaan DUDI (demand). Kerangka kerja seperti itu, dapat menjamin bahwa lebih dari separuh lulusan bisa langsung diserap menjadi tenaga kerja baik oleh DUDI pembina maupun industri lainnya. Artinya, lulusan yang memiliki keterampilan bidang kejuruan lebih cepat memperoleh pekerjaan daripada yang lainnya (Kogan \& Unt, 2008; Deissinger, 2015). Secara konseptual, pengembangan praktik belajar dan berlatih di tempat kerja akan menghasilkan budaya kerja.

Berdasarkan pemikiran tersebut, perancangan muatan-muatan kurikulum SMK dapat dimaknai sebagai pekerjaan yang dinamis bagi pengembang kurikulum. Seberapa kuat dinamika perancangan kurikulum pendidikan tersebut bergantung dengan perkembangan serta kebutuhan DUDI. Muatan berbasis moral dan kinerja harus tersirat dan tersurat ke dalam rancangan kurikulum dan berkelindan dengan bidang pekerjaannya. Muatan kecakapan kerja, kompetensi kerja, dan budaya kerja ialah kematangan nilai-nilai kerja yang dimiliki calon tenaga kerja karena merupakan hasil proses yang panjang dan lama. Muatan-muatan berbasis moral dan kinerja tersebut memiliki ciri khas, sifat khas, dan karakter khas, yang dalam kapasitas tertentu setiap nilai dapat dilatihkan atau dikuatkan melalui internalisasi dan implementasi kurikulum ke diri peserta didik.

Muatan kecakapan kerja, kompetensi kerja, dan budaya kerja adalah hal utama mengingat perspektif masyarakat terhadap lulusan SMK adalah bekerja. Karena itu, perancangan kurikulum SMK harus sesuai dan selaras serta diarahkan dengan kebutuhan DUDI. Muatan kurikulum paling tidak harus berisi keterampilan kesiapan bekerja (job readiness skills) dan keterampilan dalam pekerjaan (employability skills).

Lulusan yang kompeten dengan didukung oleh kompetensi lain yang bersifat khusus, seperti budaya kerja diyakini akan mampu menanggapi realita kondisi sosial masyarakat, keadaan lingkungan, perkembangan ilmu pengetahuan, dan penyesuaian teknologi yang terus berubah. Kurikulum SMK yang mampu menumbuhkan kompetensi lulusannya dapat dimaknai mampu mengemban tugas kewargaan (civic duty) dan sekaligus mampu menempatkan kompetensi pribadi dalam harmoni kemajuan bersama, dan memenuhi panggilan keterlibatan dalam urusan publik secara sukacita (civic joy). Kesukacitaan dalam mempersepsi pergerakan pasar tenaga kerja sebagai urusan publik yang diwarnai gejolak ketenagakerjaan akan mampu ditepisnya. Berbagai isu tersebut dapat dijadikan fokus utama pada arah pengembangan muatan kurikulum SMK.

Esensi muatan kurikulum SMK di atas dapat dikembangkan secara fleksibel dan dinamis mengikuti perubahan zaman. Muatan kurikulum harus senantiasa relevan dalam menjawab kebutuhan manusia (pendidikan) yang berkembang dari masa ke masa dan pergerakan pasar tenaga kerja. Rancangannya pun harus 
dikembangkan lebih konkrit dalam kerangka peningkatan kecakapan, komptensi, dan budaya kerja yang dilandasi penciptaan iklim hubungan industrial yang harmonis. Penyusunan muatan kurikulum dalam konsep tersebut selaras dengan kerangka konsep pengembangan Kurikulum 2013 SMK yang mengarah pada kemampuan abad 21, seperti kualitas karakter, kompetensi, literasi dasar, kemampuan berpikir kritis, kerja sama, kreativitas, dan berkomunikasi (Kementerian Pendidikan dan Kebudayaan, 2017a).

Inti muatan kurikulum SMK harus bermakna memiliki karakteristik keterampilan, kecakapan, budaya kerja, dan kemampuan yang sesuai kebutuhan DUDI. Beberapa muatan di antaranya, yakni: 1) memahami sesuatu yang diperlukan untuk pekerjaan tertentu, 2) melakukan sesuatu dengan baik, 3) membuat benda kerja sesuai spesifikasi, 4) penuh semangat ketika melakukan banyak praktik, 5) tempaan pengalaman bekerja, 6) memperoleh pengetahuan demonstratif atau pengetahuan prosedural serta pengetahuan praktis, dan 7) kesanggupan melakukan sesuatu yang baik dalam bidang pekerjaan tertentu. Muatan tersebut dibangun melalui penguatan, integrasi, dan aplikasi dalam pembelajaran pada banyak momen berlainan yang mencakup pengetahuan, sikap, dan keterampilan secara seimbang. Pendekatan pembelajaran yang kondusif adalah dengan cara observasi, imitasi, dan koreksi pribadi yang dilakukan di tempat kerja atau di tempat praktik.

Konten dari kecakapan, keterampilan, kemampuan, dan budaya kerja hendaknya disesuaikan dengan perubahan-perubahan yang terjadi di DUDI. Di samping itu juga mengadopsi strategi jangka panjang bangsa, tanggap terhadap perubahan lingkungan ekonomi global, adaptabel terhadap perubahan sistem ekonomi dan politik, dan membumikan budaya masyarakat pengikut pendidikan setempat (Clarke \& Winch, 2007; Raelin, 2008). Kerangka pikir ini memberi sinyal kuat bahwa isi muatan kurikulum SMK paling tidak merupakan pranata untuk mewujudkan budaya kerja yang berkarakter karena memiliki pengetahuan atau ilmu, keterampilan, kemampuan untuk menerapkan skill, dan attitude atau sikap dan perilaku dalam menjalankan pekerjaannya kelak. Di samping itu, diyakini bahwa intervensi pendidikan dapat meningkatkan pengetahuan dan keterampilan pekerja (Jones, Cason, \& Bond, 2004; Mendoza \& McPherson, 2017).

Dari beberapa bahasan di atas dapat disintesiskan, dimensi muatan sikap dan perilaku yang direkomendasikan untuk dibudayakan bagi peserta didik SMK di era global di antaranya, ialah: 1) memiliki karakter yang kuat, yakni berakhlak pada multilatar seperti peka emosi dan intelek, empati pada sesama, dan teguh pada prinsip; 2) berkompetensi (fasih menguasai teknologi, dan berkearifan lokal); 3) kemandirian berpikir, dalam konteks menjawab pertanyaan dan mengeluarkan pertanyaan-pertanyaan; 4) mandiri dan pengembangan diri yang berkelanjutan; 5) tawaduk dan keiklasan yang tinggi; 6) memiliki kemampuan kerja sama dalam persaingan dan persaingan dalam kerja sama; 7) memiliki sikap terbuka, menghargai kemajemukan, dan berpendirian teguh; 8) memiliki kemampuan bagaimana cara berpikir, cara belajar, dan cara membuat; dan 9) memiliki kemampuan berkecepatan tinggi, kecakapan daya suai/fleksibilitas, etos kerja, dan luas dalam jaringan.

Adanya sembilan muatan sikap dan perilaku di atas, maka kurikulum SMK tersebut akan membentuk pranata kerja profesional peserta didik. Kurikulum SMK yang sarat dengan keprofesionalan, bermakna kompetensi dan nilai attitude, terutama nilai-nilai budaya kerja. Hal ini agar peserta didik mampu mengartikulasikan bagaimana nilai-nilai tersebut memengaruhi perilaku pengambilan keputusan, meningkatkan keterampilan improvisasi, dan membantu mendapatkan rasa hormat. 
Nilai budaya kerja dalam rancangan kurikulum SMK harus selalu kompatibel dan saling melengkapi dalam satu kesatuan. Hal tersebut diperlukan mengingat pada saat peserta didik mengikuti pendidikan, konsep berpikir mereka adalah untuk: kerja, perbaikan konsep diri, pengembangan kepemimpinan, persiapan untuk belajar lebih lanjut, memeroleh penghasilan, karir lebih lanjut, dan perubahan kehidupan. Hal tersebut sesuai dengan kajian Malihah (2015) bahwa Indonesia yang kompetitif akan bergantung pada generasi sekarang dan karakter mereka untuk mampu bersaing dengan negara lain di dunia yang cepat berubah. Karenanya, setiap transformasi pendidikan, aspek paling penting adalah sumber daya manusia.

\section{Kerangka Konseptual Kurikulum Budaya Kerja}

Budaya kerja (work culture) dapat diterjemahkan sama dengan kecakapan hidup (life skills). Budaya kerja dapat pula dimaknai sebagai kesiapan dan kesigapan kerja bukan sekadar atribut profesi, melainkan juga penguasaan nilai dan keahlian terapan tertentu. Budaya kerja adalah kehidupan di tempat kerja berdasarkan aturan, nilai-nilai, prinsip-prinsip, norma, etika, dan kebiasaan yang dilaksanakan bersama. Budaya kerja menjadi pemandu, pegangan, serta diyakini oleh seluruh pekerja sehingga memunculkan sikap dan perilaku mereka.

Konsepsi budaya kerja sebagaimana di atas merupakan arena nilai-nilai yang diprogramkan untuk kehidupan Iulusan saat bekerja. Budaya kerja yang diinginkan DUDI umumnya memiliki indikator-indikator keberhasilan, misalnya berprinsip pada team-work oriented, yaitu setiap karyawan mengedepankan semangat kerja sama dalam bekerja sehingga memiliki andil yang besar terhadap kemajuan DUDI. Hasil pendidikan yang mengedepankan kecakapan kerja sama mendapat perhatian yang serius. Chapman, Matthew Meuter, Toy, \& Wright
(2006) dalam artikelnya memberi penegasan bahwa di dunia bisnis saat ini, kemampuan untuk bekerja secara efisien dan efektif dengan orang lain dalam kelompok merupakan keterampilan wajib. Keberhasilan kerja sama dapat dimaknai sebagai tuntutan kerja dan kebutuhan kerja. Karenanya, dua aspek tersebut harus mewarnai pranata budaya kerja.

Keberhasilan kerja pada dasarnya berkait dengan kualitas merek, kualitas produk, dan kualitas layanan pelanggan/jasa. Semua hal tersebut memandu terhadap keunggulan kompetitif dalam daya saing. Daya saing dalam pandangan DUDI merupakan spirit tantangan, yang kini makin kompleks membutuhkan strategi dan pendekatan baru yang berbeda. Inovasi pendekatan baru sebagai dialektika alternatif strategi yang berbeda, pada kondisi yang berbeda, dan memberikan hasil yang berbeda. Pola pikir seperti itu dikuatkan oleh Thompson (2003) untuk mengidentifikasi keunggulan kompetitif nasional yaitu sebuah pendekatan eksploratif, induktif dari spesimen ekonomi (Hong Kong), dengan menggunakan data dari 127 perusahaan. Hasilnya menunjukkan bahwa pendekatan baru yang didasarkan pada identifikasi daya saing tidak hanya di negaranegara, tetapi juga di daerah dan kota. Kajian ini memberi sinyal bahwa metode objektif dan praktis untuk mengidentifikasi daya saing nasional sangat dibutuhkan.

Kerangka konseptual budaya kerja pada kebutuhan kurikulum SMK senantiasa berhubungan dengan tuntutan kerja, kebutuhan lapangan kerja, dan daya saing pekerjaan. Tuntutan kerja, menjadi fokusnya. Sedangkan kebutuhan lapangan kerja merupakan kriterianya. Negara-negara berkembang seperti Malaysia dan Oman menurut Schütte dan Spöttl (2011) telah mengembangkan standar pekerjaan berdasarkan proses kerja inti (kumpulan fungsional benda kerja, ragam aktivitas, dan persyaratan kinerja). Hal ini didukung dengan seperangkat kompetensi (determinan kinerja) 
sebagai panduan pendidikan dan pelatihan kejuruan dalam membangun budayanya. Sintesis dari kajian ini memberi pesan kuat bahwa dalam menerapkan budaya kerja peserta didik tidak sekadar diarahkan produktif, tetapi juga harus memiliki nilai etika, moral, pemahaman terhadap pekerjaan, penalaran, kebiasaan kerja, sikap, dan perilaku kerja, kecakapan memecahkan masalah, dan efisien dalam memanfaatkan sumber daya. Selaras dengan pandangan Adhikary (2005) bahwa pendidikan dan pelatihan kejuruan harus menyiapkan peserta didik penuh makna dan produktif.

Peserta didik penuh makna artinya memiliki perspektif nilai yang cukup luas. Misalnya mengolah gagasan-gagasan yang diterimanya, sehingga bermakna untuk kehidupan yang ideal, seperti warga negara yang baik, bertanggung jawab, disiplin, jujur, pekerja keras, memiliki perilaku sosial yang baik maupun yang pragmatis, seperti kecakapan bekerja dan berkarya. Begitu idealnya, maka pengembangan budaya kerja pada kurikulum SMK sering pula dimaknakan sebagai kerangka pikir investasi sumber daya manusia (human capital investment) bagi negara. Seperangkat nilai budaya kerja akan memandu arah yang jelas, terencana baik, dan terukur bagi peserta didik, keluarga, masyarakat, bangsa, dan negara. Salah satu indikator sumber daya manusia (SDM) yang unggul apabila peserta didik mampu mengombinasikan kecakapan teknikal (technical skills) dengan kecakapan sosial (social skills). Dua kecakapan tersebut merupakan mandat profesional yang terefleksikan pada kemampuan untuk: 1) komunikasi lintas budaya; 2) berurusan dengan kerja emosional; dan 3) mengambil inisiatif dan bertindak secara mandiri sehingga pekerja berperan sebagai agen perubahan sosial (Mendes, McCurdy, Allen-Kelly, Charikar, \& Incerti, 2014; Grabowska, 2017).

Bagi SMK menghasilkan SDM yang unggul dan benar-benar dapat memberikan dampak perubahan sosial bagi masyarakat adalah poin utama. Menguatkan budaya kerja, menguatkan inovatif dan kreatif, dan menguatkan jiwa kewirausahaan menjadi modal penting bagi para Iulusan SMK agar dapat lebih siap kerja, dapat bersaing dengan negara-negara lain, dan berkontribusi nyata kepada perubahan masyarakat. Upaya mewujudkan hal tersebut dapat dilakukan antara lain melalui pengintegrasian mata pelajaran hingga menyentuh seluruh aktivitas kegiatan sekolah. Dengan demikian, diharapkan tidak ada lagi peluang melengahkan penguatan keterampilan, kemampuan, sikap, dan perilaku karena semuanya bergerak dengan rambu-rambu yang sama. Ini momen yang tepat untuk fokus menguatkan budaya kerja sebagai kebaikan peserta didik, dan untuk kembali meletakkan esensi SMK sebagai praksis penyiapan tenaga kerja.

Perkembangan DUDI seperti sekarang ini, yang serba dimudahkan dengan teknologi, peserta didik sebagai calon tenaga kerja harus pula didorong lebih fokus pada manusia dengan segala dinamikanya. Peserta didik perlu dilatih kemampuannya mempelajari tingkah laku manusia, cepat memahami, dan cepat mengambil kesimpulan yang tepat. Di tempat kerja senantiasa berkejaran dengan kompetitor yang bisa berbentuk individu atau perangkat teknologi yang diciptakan. Brodjonegoro (2018) bahwa pengembangan kapasitas sumber daya manusia di era 4.0 harus dilakukan melalui pendidikan yang memberikan kecakapan nonrutin dan kecakapan sosial. Dalam kecakapan sosial, salah satu aspek utama adalah pemahaman terhadap tingkah laku manusia. Keberhasilan mempelajari tingkah laku manusia terletak pada kemampuan individu untuk berhubungan dengan orang lain, memahami, membangun dan membina hubungan. Kerja sama, misalnya merupakan kemampuan yang direkomendasikan untuk masyarakat memasuki abad 21 . Kerja sama, dapat terbentuk dalam satu tim, kerja sama dalam persaingan, dan persaingan dalam kerja sama. 
Meskipun keterampilan STEM (science, technology, engineering, and math), dibutuhkan untuk mengembangkan perangkat-perangkat teknologi yang bisa menggantikan otak manusia, ternyata orang-orang dengan kemampuan teknis ini tetap sangat membutuhkan kemampuan sosial, kemampuan kerja sama, seperti membina hubungan secara terbuka dengan pelanggan, dan memperkuat kepercayaan dalam jejaring. Beberapa kemampuan yang direkomendasikan tersebut dapat disintesiskan sebagai budaya kerja berbasis moral dan kinerja. Rekonseptualisasi budaya kerja berbasis moral dan kinerja merupakan penataan ulang pemikiran teoretik kurikulum SMK yang rohnya tidak sekadar kecakapan teknikal, tetapi juga kecakapan sosial. Hasil penelitian Grugulis dan Vincent (2009) yang mengacu pada dua studi mengenai pekerjaan sektor publik yang dialihdayakan menemukan, bahwa softskill memberi pekerja dimensi tambahan untuk pekerjaan mereka yang dapat dipandang sebagai jalan ke depan.

Teori mengenai rancangan kurikulum sebagai pranata budaya kerja diarahkan kepada pikiran pokok bahwa konten kurikulum diartikan sebagai kemampuan melakukan sesuatu (ability to perform) berdasarkan sikap, keterampilan, dan pengetahuan. Konsep ini memperlihatkan arah yang jelas bahwa kurikulum SMK sebagai pranata budaya kerja yang dirancang perlu mensinergikan aspek-aspek kebutuhan manusia. Pengembangan soft-skils, seperti keterampilan interpersonal, keterampilan sosial, how to think, how to learn, dan how to create yang seimbang dengan hard-skills seperti keterampilan yang diperlukan, kemampuan kerja, dan kemampuan mewujudkan gagasan/produk baru. Kedua domain pengembangan ini, merupakan artikulasi penguatan budaya kerja yang juga terkait asumsi dan tata aturan yang membentuk perilaku kerja guna membangun sumber daya lulusan yang handal dan siap bekerja.
Dalam kerangka penguatan budaya kerja, tidak ada pihak yang dapat menyelesaikannya sendiri. Harus ada komitmen bersama, setidaknya dua pemangku kepentingan utama: sekolah dan masyarakat DUDI. Keberhasilan usaha-usaha ini amat bergantung pada peran yang dimainkan keduanya. Keduanya amat membutuhkan strategi nasional dan rencana aksi nasional untuk mendorong penguatan budaya kerja. Strategi ini telah menjadi kebutuhan bersama antara negara dan pengawal bidang pendidikan dalam memaksimalkan sumber daya manusia. Satu hal lagi makna budaya kerja adalah bahwa orang lain itu penting. Karena itu, dalam budaya kerja bukan hanya mampu melaksanakan pekerjaan semata, tetapi memperbanyak hubungan dengan orang lain juga tak kalah penting.

Menurut Asian Development Bank (2014) terdapat tiga faktor penting untuk memaksimalkan sumber daya manusia (SDM), yakni: 1) membangun sistem pendidikan yang fleksibel, 2) mengembangkan dan memperbarui keterampilan yang diperlukan, dan 3) meningkatkan kemampuan kerja. Kajian ilmiah Asian Development Bank ini sangat penting disikapi sebagai basis untuk merevitalisasi kurikulum SMK. Keberhasilan sekolah membangun keterampilan, kompetensi, dan budaya kerja sangat bergantung pada komitmen sekolah yang menjadi penggerak dalam meningkatkan kemampuan kerja lulusan. Menghadapi kerangka pikir ini paling tidak membutuhkan perubahan paradigma dan strategi implementasi kurikulum semua unsur pelaksana SMK.

Perubahan paradigma harus dimulai dari guru. Spektrum karakter budaya kerja mulai dibentuk di tangan mereka, sehingga saat bekerja mampu mengikuti irama DUDI. Konsep budaya kerja mestinya dipahami dengan baik oleh para peserta didik. Hal ini ditunjukkan oleh pekerja tamatan SMK karena mereka memiliki mekanisme kerja yang membentuknya sendiri. 
Pekerja memiliki budaya kerja di masing-masing perusahaannya, seperti daya tanggap dan daya suai dengan sifat pekerjaannya. Pada tiap divisi kerja, nilai-nilai kerja terintegrasi dengan karakteristik jasa dan produk kerja sehingga menjadi organisme yang mempertinggi tuntutan kerja.

Agar budaya kerja yang terbangun sesuai dengan tuntutan kerja, semua komunitas SMK yang menjadi bagian jejaring wajib memasukkan kurikulum yang menekankan kemampuan kerja, keterampilan berpikir dan berbuat dengan mengikuti irama dialektika hubungan interpersonal; kemampuan individu untuk berhubungan dengan orang lain, memahami, membangun dan membina hubungan; dan kemampuan sosial, seperti pemahaman kebutuhan konsumen. Bekerja, bukan semata harus produktif, melainkan juga membutuhkan keterampilan dan kompetensi lain yang dipersyaratkan pekerjaan.

Semua sikap, perilaku, keterampilan, dan kompetensi kerja sebagaimana diuraikan di atas, dapat dimaknai sebagai yang dibutuhkan DUDI di era global yang cepat berubah ini. Ekosistem korporasi juga berubah sesuai dengan harapan dan kebutuhan pelanggan yang juga berubah dengan cepat. Perubahan kebutuhan DUDI terjadi karena percepatan perkembangan teknologi, tingginya harapan pelanggan, dan demografi yang bergeser dan memudar batasannya menyebabkan perubahan dalam cara hidup. Cara hidup bangsa selalu dianggap penting karena secara tidak langsung menggambarkan budaya kerja masyarakatnya.

Budaya kerja masyarakat DUDI menurut Van den Broeck, De Cuyper, Luyckx, \& De Witte (2012) menunjukkan bahwa tuntutan kerja dan sumber daya pekerjaan terjadi dalam empat profil: 1) menuntut, artinya tuntutan tinggi dan sumber daya rendah); 2) akal, artinya tuntutan rendah dan sumber daya tinggi; 3) miskin, artinya tuntutan rendah dan sumber daya rendah; dan 4) pekerjaan yang kaya, artinya permintaan tinggi dan sumber daya tinggi. Hasil penelitian ini memberi pesan kuat bahwa SDM yang unggul akan mampu menghasilkan budaya pekerja terampil tinggi yang memandang bekerja sebagai modal daya saing. Untuk menghasilkan pekerja terampil, perancangan kurikulum SMK harus dikembalikan kepada etika dan etos kerja pada jantung budaya kerja.

Budaya kerja yang mampu mendorong daya saing bangsa juga tidak kalah penting. SMK yang menghasilkan budaya kerja yang mumpuni belum banyak. Bukan pada pengembangan model internalisasi nilai-nilai budaya kerja yang mampu menumbuhkembangkan kinerja peserta didik. Terobosan yang membudayakan budaya kerja di sekolah yang mesti dipikirkan. Transformasi budaya kerja di sekolah dapat dilihat dari dua indikator luaran. Pertama, apakah proses pembelajaran dan kegiatan lainnya bisa menghasilkan lulusan yang kuat budaya kerjanya. Kedua, apakah budaya kelas dan budaya sekolah menghasilkan transformasi budaya kerja. Budaya kerja dibentuk dengan upaya keras melalui pembiasaan mengerjakan tugas-tugas yang diberikan guru agar peserta didik memiliki kemampuan hidup paling hakiki: mampu bekerja dan mencari penghidupan.

Salah satu instrumen yang bisa dimanfaatkan untuk mengikuti ritme DUDI dan mendorong budaya kerja adalah seperangkat muatan kurikulum dan program pembudayaan sekolah. SMK yang mampu menguatkan internalisasi nilai-nilai budaya kerja pada perkembangan peserta didik, misalnya didorong kebijakan yang menyinergikan antara sekolah dan DUDI. Semua upaya menginternalisasikan nilai-nilai budaya kerja memang memerlukan sinergisitas berbagai pihak. Bukan hanya DUDI, melainkan juga dinas pendidikan di daerah setempat mesti juga bergerak. Masyarakat DUDI pun tidak hanya menjadi objek, tetapi juga mesti didorong berperan semakin kuat. Dari pendekatan ini, peserta didik yang berlatih langsung di DUDI dengan sistem kemitraan 
memperoleh wawasan seperti apa pekerjaan tersebut nantinya dan mencari tahu apakah itu sesuai untuk mereka, di samping mereka terbiasa dengan budaya kerja.

Dengan berbagai pendekatan model sistem pendidikan bermitra, seperti pendekatan akademik, kecakapan hidup, berbasis kompetensi, berbasis luas dan mendasar, berbasis produksi didorong menjadi suatu kelengkapan landasan nilai filosofisnya, yaitu yang dapat menguatkan budaya kerja. Selaras dengan hasil penelitian Doyle (2012) bahwa pendekatan yang didasarkan kepada hal yang saling menguntungkan antara pembelajaran kejuruan (kecakapan dan budaya kerja) dan akademis dapat menawarkan peningkatan keterampilan, pengetahuan, dan pemahaman kaum muda. Dengan demikian, budaya kerja menguat, bermanfaat, dan tidak hanya sebagai jargon dan mitos di sekolah, tetapi mendongkrak harapan anak muda bersekolah.

Pada umumnya peserta didik SMK berada dalam posisi yang kurang beruntung mengenai pilihan jalur sekolah menengah mereka. Sekolah di SMK berharap segera bisa bekerja. Adagiumnya, bisa menggapai kehidupan. Premis tersebut mendapat penguatan dari Kiprianos dan Christodoulou (2015) terkait tentang yang dipikirkan dan dirasakan peserta didik tentang pendidikan mereka. Kiprianos dan Christodoulou berpendapat bahwa remaja masa kini tidak secara terbuka menolak pelatihan kejuruan. Mereka mencoba untuk mengubah keterampilan dan pengetahuan tidak resmi yang diperoleh dalam budaya mereka menjadi modal budaya resmi yang mampu membuat mereka memasuki pasar kerja.

Dengan diterima kerja, lulusan SMK selain memiliki budaya kerja dan kecakapan kerja sekaligus juga berperan mengurangi dampak sosial negatif bagi bangsanya. Hasil studi Rosen, Weiss, Zancanaro, dan Gal (2017) menemukan bahwa kesiapan kerja tampaknya memiliki kegunaan dan validitas sosial yang baik.
Eichhorst, Rodríguez-Planas, Schmidl, \& Zimmermann (2015) dalam penelitiannya tentang pendidikan dan pelatihan kejuruan (VET) di negara-negara industri menemukan bahwa VET adalah alternatif yang bernilai di luar inti pendidikan umum. Masyarakat pendidikan yang dilatih bidang kejuruan tertentu akan memiliki kesiapan kerja yang akan berdampak terhadap pertumbuhan ekonomi. Kesiapan kerja, berarti mengarah pada pembentukan kecakapan dan budaya kerja yang berkaitan dengan pelaksanaan tugas pekerjaan tertentu.

Pembahasan tentang budaya kerja yang perlu ada dalam muatan kurikulum SMK selalu dikaitkan dengan karakteristik bidang pekerjaan. Lulusan SMK akan disiapkan untuk bekerja atau latih bekerja pada bidang pekerjaan tertentu. Kedua isu tersebut senantiasa berkelindan manakala akan mengembangkan nilai-nilai budaya kerja dalam kurikulum SMK. Karena kedua pendekatan memiliki perbedaan dan karakteristik makna yang cukup signifikan, yang akan memandu dalam perancangan budaya kerja, baik pada tataran konsep, isi maupun pada domain pengimplementasiannya. Domain peran SMK tersebut teramat penting, baik yang diselenggarakan di sekolah, di DUDI, maupun di masyarakat. Melalui sistem SMK yang baik akan mengarahkan budaya kerja masa depan. Karena itu, kualitas implementasi kurikulum menentukan pula kualitas budaya kerja almamaternya.

Implementasi kurikulum SMK harus berisikan nilai-nilai dan kompetensi spesifik dan tunggal berkait bidang pekerjaan yang dibutuhkan DUDI. Apabila lulusan diarahkan untuk siap latih bekerja pada berbagai bidang, berarti budaya kerja yang berintikan nilai-nilai konten kurikulumnya berisikan kompetensi-kompetensi yang bersifat general, majemuk, berdaya suai, dan prediksi dari beragam bidang pekerjaan masa depan. Trocchia, Swanson, dan Orlitzky (2007) memberikan bukti bahwa peserta didik akan mengalami pemahaman yang lebih besar mengenai nilai mereka sendiri setelah 
berpartisipasi dalam latihan kerja. Nilai-nilai yang dipegang secara pribadi memainkan peran mendasar dalam bekerja. Dengan demikian, sangat penting bahwa mereka memahami sifat nilai yang berkaitan dengan tempat kerja.

Belum banyak kajian tentang kurikulum kejuruan yang mengupas tentang budaya kerja. Menurut Wallace dan Leicht (2004) budaya kerja memiliki hubungan yang rumit dan kompleks, yakni antara nilai budaya dengan ideologi berbasis kerja dan pandangan pekerja mengenai hak kerja. Rumitnya hubungan bukan hanya terkait sikap, perilaku, dan keterampilan kerja, seperti disiplin, tanggung jawab, etika, kerja sama, berempati, komunikasi, ekonomis, efisien, dan efektif melainkan juga berkait dengan domain budaya yang lebih luas, seperti persamaan sosial, kebebasan sosial, multikulturalisme, dan keadilan gender. Budaya kerja yang baik sangat ditentukan sikap kerja profesional pelakunya dan juga seberapa kuat ia mau belajar dari semua situasi yang muncul di tempat kerja.

Budaya kerja merupakan konsep abstrak mengenai perilaku individu dalam komunitas kemasyarakatan yang berbentuk nilai-nilai yang penting saat seseorang menghadapi pekerjaan. Nilai-nilai budaya dan logika harus sebagai abstraksi perbuatan pribadi yang paling strategis sebagai sistem pesan utama dalam pendidikan untuk memulai pekerjaan di industri (Ashton, 2013; Warren, 2014; Lizardo, 2016; Gale, Mills, \& Cross, 2017). Perbuatan pribadi erat hubungannya dengan budaya kerja yang diinginkan oleh DUDI yang pada umumnya memiliki indikator-indikator nilai sebagai kunci keberhasilan. Kunci keberhasilan yang dimaksud antara lain berkaitan dengan konsensual tentang sifat kerja, kualitas merek, kualitas produk, dan layanan pelanggan yang kesemuanya harus memandu terhadap keunggulan kompetitif yang berbeda dari DUDI. Bangunan pranata budaya kerja yang mampu mengikat setiap orang terlibat secara sadar diri mematuhi dan melaksanakan seluruh kebijakan yang telah ditetapkan bersama berdasarkan nilai-nilai dasar bekerja yang akan berdampak terhadap kinerja tempat produksi.

Nilai-nilai dasar bekerja merupakan seperangkat pedoman tentang tabiat, sikap, perilaku, dan pola pikir pekerja yang umumnya dalam rangka mewujudkan cita-cita tempat bekerja. Misalnya, perusahaan Google terkenal dengan slogan users first dan nilai "Don't be Evil". Contoh lain, perusahaan Telkom dengan budaya kerjanya Always The Best (ATB). Kedua contoh tersebut memberi panduan di tempat kerja bahwa untuk memberikan hasil kerja yang terbaik dalam bekerja, seseorang harus memiliki spirit menjunjung tinggi budaya tempat kerja. Terkait dengan budaya tempat bekerja, banyak faktor yang memengaruhinya. Pada konteks lain, pegawai di Kemendikbud, diharuskan memiliki tujuh tata nilai budaya kerja, yakni: 1) memiliki integritas, 2) kreatif dan inovatif, 3) inisiatif, 4) pembelajar, 5) menjunjung meritokrasi, 6) terlibat aktif, dan 7) tanpa pamrih (Kementerian Pendidikan dan Kebudayaan, 2017b).

Budaya kerja adalah cara pandang institusi atau perusahaan atau seseorang dalam memaknai kerja pada suatu bidang pekerjaan. Bidang-bidang pekerjaan yang dijalani DUDI atau seseorang harus menjadi prinsip-prinsip dasar yang diyakininya untuk melakukan yang terbaik dalam bekerja. Wujud budaya kerja merupakan sekumpulan sikap, perilaku, dan moral yang harus dipatuhi oleh setiap pekerja. Dalam tataran konseptual, sikap dan perilaku pekerja menurut Ndraha (2010) mencakup komponen: 1) sikap terhadap pekerjaan, 2) anggapan dasar tentang kerja, 3) perilaku ketika bekerja, 4) lingkungan kerja dan peralatan kerja, dan 5) etos kerja. Lima komponen tersebut dapat dimaknai sebagai jembatan antara rancangan kurikulum SMK dengan tuntutan dan kebutuhan tempat kerja yang lazimnya disebut pranata kerja.

Terkait dengan pranata kerja, Stewart dan Pepper (2010) dalam penelitiannya tentang cara 
merevitalisasi ekonomi masyarakat Indian, Amerika menawarkan bahwa perubahan kurikulum mesti sesuai dengan budaya. Tantangan utama program kurikulum tersebut adalah pada integrasi nilai-nilai budaya asli dan praktik manajemen dengan kurikulum bisnis. Terintegrasinya nilai-nilai budaya kerja dalam implementasi kurikulum mesti dipahami dengan baik sebagaimana ditunjukkan oleh orang-orang yang telah bekerja. Budaya kerja semacam ini memiliki ciri khas, sifat khas, dan karakter khas yang dalam gradasi setiap nilai dapat dilatihkan atau dikuatkan ke diri peserta didik di SMK.

Kerangka konseptual muatan kurikulum budaya kerja ialah kematangan nilai-nilai kerja utama yang dimiliki calon tenaga kerja yang merupakan hasil pembelajaran dengan proses panjang yang mencakup akhlak mulia pada multilatar, sikap, keterampilan, kemampuan, kecakapan, perilaku, dan fasih menggunakan teknologi. Secara akademik, kerangka konseptual budaya kerja dapat dimaknai sebagai pendidikan nilai yang tujuannya mengembangkan budaya peserta didik. Tujuannya adalah memiliki keputusan baik atau buruk dalam bekerja, memelihara apa yang baik dalam bekerja, dan mewujudkan kebaikan itu dalam kehidupan sehari-hari di tempat kerja dengan sepenuh hati.

\section{Menginternalisasikan Budaya Kerja}

Setiap SMK memiliki pemahaman dan narasi budaya kerja yang ingin ditumbuhkembangkan dan dilatihkan kepada setiap peserta didik melalui pembelajaran. Pembelajaran untuk mata-mata pelajaran kejuruan lazimnya sekaligus sebagai medium internalisasi budaya kerja. Penginternalisasian nilai-nilai selalu dikaitkan dengan proses-proses praktik kejuruan, seperti di kelas, di bengkel/laboratorium, dan di tempat praktik industri. Namun, banyak SMK yang masih belum yakin apakah budaya kerja yang dikembangkan di sekolah sudah efektif terinternalisasi dan nyata berlaku pada DUDI sesuai karakteristik bidang kejuruannya.
Untuk menjawab pertanyaan tersebut dibutuhkan evaluasi budaya kerja yang diimplementasikan di sekolah. Sementara itu, mengevaluasi budaya kerja juga tidak mudah karena perilaku setiap peserta didik tidak mudah diidentifikasikan. Dalam konteks risalah ini bukan proses mengevaluasi budaya kerja yang akan disampaikan, melainkan apakah proses internalisasi nilai-nilai budaya kerja di sekolah telah berjalan dengan baik. Penginternalisasian nilai-nilai budaya kerja bisa dilakukan paling tidak dengan tiga pola yaitu: 1) internalisasi nilainilai senantiasa diselaraskan dengan strategi kerja, 2) internalisasi nilai-nilai senantiasa diselaraskan dengan karakteristik proses produksi perusahaan, dan 3) internalisasi nilainilai senantiasa diselaraskan dengan hubungan kerja dan karakteristik pekerjaan.

Nilai-nilai budaya kerja dapat diupayakan dalam pembelajaran di sekolah secara luas dan integratif. Budaya kerja diperoleh dengan mengintegrasikan, menyatupadukan, bukan menyempitkan, menyendirikan, apalagi dianggap sebagai teori yang harus diajarkan. Fenomena menguatnya kebutuhan budaya kerja ini membangkitkan kesadaran akan pentingnya sebuah nilai dalam pelaksanaan kurikulum sekolah. Hal ini menyadarkan ketika lulusan SMK ditolak oleh DUDI, maka semangat menguatkan budaya kerja ke dalam kurikulum menjadi penting. Masalah yang melatari fenomena ini harus segera dijawab secara bijaksana melalui kurikulum.

Dalam praksis kehidupan sehari-hari, semangat penguatan internalisasi nilai-nilai budaya kerja bisa dilakukan di lingkungan keluarga, sekolah, dan masyarakat. Kata kunci yang tepat untuk menguatkan nilai-nilai budaya kerja adalah adanya program sekolah yang jelas, adanya kemauan peserta didik, dan adanya komitmen komunitas untuk melakukan. Upaya memperkuat nilai budaya kerja ini kemudian menjadi panggilan semua pemangku kepentingan pendidikan SMK untuk terlibat secara aktif di 
dalamnya. Dalam menguatkan budaya kerja ini, semua pemangku kepentingan harus menjadi model dan teladan bagi peserta didik, baik itu orangtua, pendidik, tenaga kependidikan, teman sebaya, dan masyarakat lingkungan sekolah. Kerangka logis dari upaya itu sangat penting karena dengan keteladanan dan pemodelan, akan banyak nilai-nilai budaya kerja bisa dilakukan.

Hal-hal yang dapat dipelajari dan dilakukan oleh pendidik dan tenaga kependidikan di sekolah adalah nilai-nilai budaya kerja muncul dari aktivitas belajar karena memang tidak ada pembelajaran khusus melatihkan hal tersebut. Setiap momen pembelajaran, baik mata pelajaran umum maupun kejuruan memiliki dinamika dan pergolakan serta tantangan sendiri untuk melatihkan kemauan bekerja. Kurikulum 2013 sudah berada pada desain dan jalan yang benar. Keyakinan itu diperkuat oleh konsep yang jelas dalam Naskah Akademik Pengembangan Kurikulum, bahwa rancangan kurikulum tersebut: 1) berbasis kompetensi, 2) pengembangan softskills yang seimbang dengan hard-skills, 3) mengarah ke visi masa depan Indonesia dalam kehidupan global abad ke-21, dan 4) pengembangan kecerdasan intelektual, karakter, kompetensi, literasi, kreativitas, dan berpikir kritis (Kementerian Pendidikan dan Kebudayaan, 2011).

Kedua, urgensi menjawab tantangan untuk penguatan nilai-nilai budaya kerja peserta didik SMK saat ini mesti menjadikan dorongan penyadaran. Kesadaran praktisi pendidikan kejuruan di lapangan sangatlah diharapkan. Itu semua sangat penting untuk berhasilnya lulusan yang memiliki budaya kerja mumpuni. Selain revitalisasi pendidikan vokasi pada SMK, sebagaimana dimandatkan oleh Instruksi Presiden Nomor 9 Tahun 2016, yang juga sangat mendesak untuk terus diwujudkan selain nilainilai budaya kerja adalah pentingnya menggalakkan kompetensi kerja yang disertai penciptaan iklim kerja di sekolah.
Faktor determinan dalam pembentukan budaya kerja adalah adanya iklim kerja di sekolah yang sistematis mengarahkan keterampilan kerja untuk meningkatkan kapasitas, kapabilitas, dan kompetensi peserta didik adaptif dengan budaya kerja yang dimiliki DUDI. Salah satu ciri budaya yang dimiliki hampir semua DUDI adalah strategi kerja. Berhasil maupun ketidakberhasilan DUDI sangat bergantung dengan strategi kerja yang diterapkan. Misalnya, DUDI yang sangat mengandalkan pelayanan prima, maka budaya kerja layanan menjadi keniscayaan. Sementara itu, DUDI yang mengandalkan keunggulan kompetitif hasil produknya akan sangat memedulikan efisiensi kerja dan standarisasi kerja, bukan bentuk layanan prima. Namun, pelayanan kepada pelanggan tetap merupakan aspek yang perlu diperhatikan.

Layanan DUDI semakian kompetitif dengan paradigma yang tidak akan mampu mendegradasi kesenjangan pendapatan perusahaan. Budaya kerja tumbuh dari hati nurani peserta didik SMK, suatu kebiasaan yang terbangun oleh kemauan dan komitmen dalam melaksanakan pekerjaan secara sungguhsungguh. Tumbuhnya nilai-nilai budaya kerja bisa diupayakan. Bendassolli dan Tateo (2018) menjelaskan bahwa budaya ditransmisikan ke orang-orang, terutama merupakan upaya bersama berdasarkan nilai bersama.

Nilai-nilai penting bersama dalam budaya kerja lazimnya selaras dengan proses produksi DUDI bersangkutan. Proses yang diterapkan umumnya berkaitan dengan budaya kerja karyawan yang mampu mendukung kualitas proses jasa dan produksi yang diinginkan termasuk penggunaan waktu kerja yang efisien dan pencegahan kesalahan kerja. Misalnya, DUDI yang mengedepankan faktor kecepatan perlu didukung nilai budaya kerja karyawan yang terlatih secara baik dalam hal pengambilan keputusan. Sementara itu, DUDI lainnya yang mengandalkan proses produksi mengedepankan keakuratan tinggi perlu didukung oleh karyawan 
yang memiliki budaya kerja konsistensi melaksanakan pekerjaan yang baik. Kerangka filosofis tersebut menjadi kunci keberhasilan proses jasa dan produksi yang diterapkan oleh DUDI, yang sangat dipengaruhi oleh kuat tidaknya budaya kerja para karyawan di dalamnya.

Lulusan SMK sebagai calon karyawan yang bersifat pluralistik dan berkarakter Indonesia diharapkan memiliki keterampilan kerja, kompetensi kerja, budaya kerja, dan etos kerja juga mampu mendorong terbentuknya tatanan masyarakat yang: 1) menghargai perbedaan pendapat sebagai manifestasi dari rasa tanggungjawab dan kepedulian terhadap kehidupan berbangsa dan bernegara serta pemantapan kehidupan demokrasi di semua bidang pekerjaan; 2) tertib, sadar hukum, memiliki budaya malu, jujur, dan mampu menciptakan keteladanan di tempat kerja; dan 3) memiliki rasa percaya diri, mandiri, kreatif, memiliki etos kerja tinggi, berorientasi terhadap penguasaan ilmu pengetahuan dan teknologi dalam rangka memacu keunggulan bangsa dalam kerangka persaingan dunia. Inilah esensi dari Instruksi Presiden Republik Indonesia Nomor 9 Tahun 2016 tentang Revitalisasi Sekolah Menengah Kejuruan dalam Rangka Peningkatan Kualitas dan Daya Saing Sumber Daya Manusia Indonesia.

Tenaga kerja yang berdaya saing, berkarakter, dan terampil salah satu di antaranya dilahirkan dari SMK yang bermutu dan relevan dengan tuntutan DUDI yang terus menerus berkembang. Lulusan SMK hendaknya berkarakter baik, memiliki daya yang mumpuni, dan berbudaya kerja baik bagi bangsa ini. Karakter dapat dipercaya dan diyakini menjadi sangat penting karena nilai-nilai yang membentuknya sangat berguna untuk kehidupan, seperti kejujuran. Kejujuran dapat menumbuhkan kepercayaan pekerja. Sebaliknya, kebohongan akan menumbuhkan kecurigaan dan dapat menghambat setiap urusan pekerjaan.
Budaya kerja dapat pula dimaknai sebagai elemen nilai pendorong dalam bekerja. Dalam konteks ini, kepala SMK berperan meningkatkan budaya kerja dengan memberikan gambaran visi ke depan yang jelas yang memiliki peluang penguatan nilai-nilai budaya kerja. Misalnya, ketika peserta didik berada dalam sekolah yang penuh ragam pembelajaran, pelatihan, dan jenis pekerjaan, sekolah harus memiliki strategi dan program kerja yang unggul dan spesifik untuk menginternalisasikan nilai-nilai budaya kerja yang dikuatkan. Kepala sekolah dapat mendorong perubahan untuk memberi optimisme jalan yang berbeda atau lebih baik. Wakil kepala sekolah bidang kurikulum dapat berperan mengomunikasikan strategi kebijakan kepada semua warga sekolah untuk menciptakan optimisme dan harapan. Dengan demikian, esensi dari internalisasi nilai-nilai kerja adalah mengembalikan etos kerja pada budaya kerja.

\section{Tanggung Jawab yang Dilakukan Sekolah}

Posisi, peran, dan fungsi budaya kerja selayaknya menjadi bagian dari strategi pembelajaran di sekolah. Pembelajaran yang imperatif berpengaruh besar pada penguatan budaya kerja peserta didik. Dalam konteks inilah sekolah harus membahas suatu kasus dan isu kebijakan terkait internalisasi nilai-nilai budaya kerja secara komprehensif, terpadu, holistik, dan tidak asal-asalan.

Tantangan terkait tanggung jawab dalam kerangka penguatan budaya kerja akan sangat bergantung pada upaya sekolah mendorong dan memfasilitasi penginternalisasian nilai-nilai di sekolah. Kepala sekolah beserta para pendidiknya harus memiliki semangat kepedulian yang tinggi pada apa yang peserta didik harapkan. Mereka bisa merancang kebijakan tentang bagaimana bergerak, bagaimana sebuah nilai-nilai budaya kerja dikuatkan di sekolah. Kerangka pikir dari kepala SMK pembuat kebijakan di sekolah merupakan kunci keberhasilan kualitas nilai-nilai. Proses 
pembuatan kebijakan, tanpa meninggalkan kepentingan peserta didik menjadi poros kepentingan lulusan dalam menghadapi strategi kerja yang diterapkan DUDI.

Tanggung jawab sekolah harus diluruskan dengan mengembalikan fungsi utama lembaga pendidikan tersebut. Salah satu yang mendorong keberadaan SMK adalah membekali peserta didik untuk terjun ke masyarakat (Departemen Pendidikan dan Kebudayaan, 1996). Secara rasional SMK efektif jika menjamin pengadaan tenaga kerja secara memadai. Satu prinsip dasar SMK adalah peserta didik dilatih pada ranah pekerjaan yang sesuai dan dibutuhkan pasar sebagai demand. Konteks ini yang harus senantiasa dipahami pihak kepala sekolah beserta tenaga pendidiknya. Meningkatnya pemahaman dan apresiasi komunitas sekolah terhadap budaya kerja menjadi tantangan tersendiri bagi setiap SMK untuk meningkatkan layanan pendidikan yang sarat dengan nilai-nilai budaya kerja bagi peserta didik secara sungguhsungguh.

Tantangan SMK saat sekarang semakin kompleks. Mulai dari kesempatan kerja yang semakin berkurang karena hadirnya teknologi digital, seperti kecerdasan buatan (artificial intelligence/AI), kompetisi pencarian kerja yang ketat, hingga kesenjangan antarsekolah. Oleh karena itu, tuntutan kepada kepala SMK di samping tugas-tugas administratif, seperti mampu memprioritaskan kebutuhan kompetensi dan budaya kerja serta pembudayaan lain yang bervariasi, kepala sekolah mampu mengemban tugas manajerial yang mumpuni. Tantangan mengelola sekolah semakin penting, termasuk tantangan untuk membangun budaya kerja peserta didik. Hal ini adalah yang paling rumit. Dengan aneka ragam kompetensi yang dibutuhkan DUDI dan cepatnya perubahan yang terjadi, SMK sebagai garda terdepan penghasil Iulusan harus dengan cepat bergerak secara luwes, meskipun tetap menjaga kaidah-kaidah kompetensi kerja dan budaya kerja sesuai bidangnya. Begitu pula peserta didik juga dituntut untuk terus belajar keras karena perkembangan kompetensi dan budaya kerja juga begitu cepat terjadi, dan selalu ada hal baru yang muncul.

Kepala sekolah bersama guru dan peserta didik harus terbiasa dengan perubahan budaya kerja di DUDI, termasuk perpindahan dari pekerjaan yang satu ke jenis pekerjaan lainnya yang terkadang tidak ada kaitannya dengan pekerjaan terdahulu. Tugas sekolah adalah menghasilkan lulusan SMK yang siap dan sigap akibat banyaknya perubahan yang terjadi, sementara kinerja sekolah pun harus tetap dijaga. Terlebih, pada era digital ini sekolah harus berfokus pada skills dan budaya kerja untuk menyiapkan lulusannya terjun ke DUDI dan masyarakat.

Terjun ke masyarakat memiliki spektrum yang luas, yang maknanya mampu mencari penghidupan sendiri, yakni: 1) bekerja secara mandiri, 2) bekerja dengan orang lain, dan 3) bekerja sebagai karyawan pada institusi formal/ DUDI. Dalam kerangka pikir seperti ini, pembahasan mengenai tanggung jawab lembaga pendidikan terhadap implementasi kurikulum dan program pendidikan diarahkan pada mutu dan relevansi pekerjaan. Dalam era yang penuh persaingan di masa depan yang perkembangannya sulit diprediksikan, mutu dan kesesuaian lulusan SMK dengan kebutuhan dan budaya kerja harus menjadi semangatnya. Karena itu, sekolah juga dituntut untuk berbenah, terus berubah serta berkembang ke arah yang sama, yaitu melatihkan dan menguatkan kompetensi dan budaya kerja.

Peran SMK melatihkan kompetensi untuk bekerja dan sekaligus menginternalisasikan nilainilai budaya kerja di sekolah maupun di luar sekolah bagi peserta didiknya. Secara program telah banyak kebijakan pemagangan untuk mendorong dua dimensi dapat terwujud. Misalnya, SMK selama ini diwajibkan menerapkan program kemitraan dengan DUDI seperti kelas 
industri dan kewirausahaan, praktik pengalaman lapangan (PPL), praktik kerja lapangan (PKL), praktik kerja industri (Prakerin), konsep link and match dengan model pendidikan sistem ganda (PSG), kelas unit produksi, dan sebutan lainnya.

Banyak temuan bahwa program pemagangan tersebut masih kurang fokus. Peserta didik praktik kerja di DUDI, tetapi sebenarnya pratik kerja untuk menjawab kebutuhan apa? Masih banyak ditemukan, misalnya bidang keahlian bisnis dan manajemen yang hanya sekadar ditugasi memfotokopi, menata dokumen di perpustakaan, mengantar surat, atau pun tugas lain yang tak ada hubungannya dengan kompetensi keahliannya. Ketika SMK tidak sanggup memberikan fasilitas secara optimal dalam konteks pemagangan dalam kerangka pelatihan kerja untuk menyesuaikan kebutuhan, maka kualifikasi kemampuan, keterampilan, dan budaya kerja peserta didik akan menuai persoalan.

Bentuk pertanggungjawaban sekolah agar peserta didik tidak memiliki persoalan berkaitan dengan kompetensi kerja dan budaya kerja bisa dilakukan hal berikut. Apabila program pembelajaran di sekolah merupakan aktivitas yang harus dilakukan, maka pihak sekolah harus mengupayakan agar kegiatan tersebut dilakukan dengan perubahan cara berpikir semua pemangku kepentingan tentang konsepsi manusia sebagai sumber produktivitas, baik untuk kepentingan jasa maupun produk. Produktivitas tidak hanya memerlukan keterampilan motorik, tetapi juga keterampilan sosial, keterampilan manajerial, keterampilan bekerja sama, dan keterampilan intelektual. Keterampilan tersebut sarat dengan kecakapan lain, seperti penggunaan pikiran dan akal, penalaran, penemuan ide, dan kreativitas dalam mengerjakan sesuatu menjadi lebih bermakna. Sehingga hal tersebut menghasilkan sebuah nilai dari hasil pekerjaan yang lebih baik. Agran, Hughes, Thoma, \& Scott, (2016) dalam penelitiannya menemukan bahwa keterampilan yang dianggap paling penting bukanlah keterampilan yang paling sering diajarkan.

Dalam konteks kompetensi kerja dan budaya kerja sebagaimana di atas, sebaiknya membuat semua pemangku kepentingan menyadari bahwa budaya kerja ada di mana-mana dan bukan mencari ke mana-mana. Penerapan kurikulum budaya kerja tersebut harus lebih luwes, lebih lembut, dan bergerak membudayakan peserta didik sehingga semua tamatan bisa bekerja dan dapat menjadi warga negara yang lebih baik. Kompetensi bekerja bukan satu-satunya faktor yang dapat menunjang produktivitas dan kinerja. Dengan penguatan ragam kompetensi yang memiliki tingkatan semakin tinggi dan disertai dengan penginternalisasian nilai-nilai budaya kerja, lulusan SMK dapat memainkan peran sebagai sumber penggerak jasa dan produksi di DUDI. Prinsip tersebut dapat dijadikan pendorong dan dasar bagi penanggung jawab sekolah dalam implementasi kurikulum SMK untuk menghasilkan lulusan siap kerja. Artinya, sekolah harus kuat dalam mengimplementasikan kurikulum budaya kerja dengan unsur dan isinya yang berkait dengan proses kerja dan produksi berdasarkan kompetensi.

Dengan kerangka pemikiran kurikulum seperti itu, paling tidak terdapat dua peran dan tanggung jawab SMK dalam pengembangan dan pengayaan kompetensi bekerja dan budaya kerja. Pertama, sekolah harus mampu menghadirkan pembelajaran berkualitas untuk semua mata pelajaran. Hal ini sejalan dengan rencana ke depan untuk revitalisasi dan sekaligus meneguhkan SMK sebagai technosocio-entrepreneurial senior education. Apalagi saat ini, lulusan SMK dihadapkan pada era disrupsi yang penuh dengan ketidakpastian dan kompleksitas. Sekolah harus mendorong sinyalsinyal perubahan, cara berpikir, cara bertindak, orientasi budaya kerja, proses produksi, tuntutan layanan jasa maupun pengelolaan kelas. Manajemen SMK juga harus adaptif dengan generasi milenial yang tentu butuh 
pendekatan serba milenial, misalnya dengan penguatan teknologi informasi dan komunikasi dalam pembelajaran.

Di samping itu, penguatan peran dan tanggung jawab SMK saat sekarang juga dituntut untuk menghasilkan lulusan yang memiliki daya suai terhadap perubahan melalui tumbuhnya technopreneur dengan pengembangan lulusan melalui inovasi yang dikreasikan. Inovasi yang konkrit dalam internalisasi nilai budaya kerja dibutuhkan untuk mendorong kompetisi bekerja. Hal tersebut untuk menanggulangi kesiapan kerja yang dapat memperkuat ekonomi nasional, termasuk mendukung arah dan kebijakan pembangunan nasional. Keberhasilan pembangunan nasional suatu bangsa bergantung pula pada seberapa baik perkembangan kewirausahaan (entrepreneurship) pada masyarakat di negara tersebut, karena kecakapan entrepreneurship merupakan kunci keberhasilan perekonomian suatu negara.

Kuatnya kompetensi entrepreneurship lulusan akan berdampak pada kinerja saat mereka memasuki dunia kerja, yang akan menghasilkan kualitas produksi di DUDI. Kualitas produksi turut memegang peranan penting dalam pembangunan ekonomi. Ekonomi dan pendidikan di SMK memiliki hubungan yang bersifat saling menguntungkan. Lulusan SMK yang memiliki kecakapan entrepreneurship yang baik akan mampu meningkatkan pertumbuhan ekonomi. Salah satu indikator pertumbuhan ekonomi adalah ada kenaikan kualitas produk yang dihasilkan oleh DUDI. Lazimnya, pekerja yang memiliki kecakapan entrepreneurship yang baik juga melakukan inovasi. Inovasi memiliki makna luas, tidak hanya menyangkut penemuan teknik-teknik berproduksi baru, tetapi juga penemuan komoditas baru, jenis material baru untuk produksi, cara-cara usaha baru, caracara pemasaran baru, pemanfaatan teknologi baru, dan kombinasi-kombinasi baru.

Kedua, pada saat peserta didik akan melaksanakan praktik kerja nyata, setiap SMK melakukan analisis keseimbangan antara peserta didik dan ketersediaan bidang pekerjaan yang terdapat di DUDI. Hal ini untuk mengetahui apakah kompetensi bekerja yang ditempuh oleh mereka relevan dengan persediaan kerja. Berdasarkan konsep ini seluruh isi muatan kurikulum, proses jasa dan produksi, dan penilaian praktik harus dikaitkan dengan kebutuhan kompetensi peserta didik dan budaya kerja, sehingga hasil dari praktik kerja lapangan menjadi sepadan dengan kebutuhan DUDI. Dalam konteks ini, kedua struktur tersebut dikaji dengan cara disejajarkan. Tujuan utama analisis keseimbangan ini ialah untuk mengkaji lebih jauh apakah persediaan kompetensi yang dimiliki peserta didik secara mikro dapat dikuatkan dalam proses jasa dan produksi di DUDI melalui sistem yang dibangun.

Salah satu indikator keberhasilan praktik pemagangan peserta didik di DUDI adalah keseimbangan antara bekal kompetensi dari proses pembelajaran dengan kesempatan praktik pemagangan di DUDI terdapat keterkaitan dan kesepadanan. Ketika peserta didik telah dapat didayagunakan secara optimal di DUDI, secara makro tanggung jawab sekolah dapat dikatakan telah memberikan kepercayaan melalui pola kemitraan sepadan dengan kebutuhan DUDI. Situasi kemitraan dengan DUDI seperti itu akan memberikan kesempatan kerja (employment) yang lebih luas kepada lulusan SMK. Pada konteks itu, Sahlberg (2014) pernah menyatakan bahwa kunci keberhasilan pendidikan Finlandia adalah penguatan sekolah dengan memberikan kepercayaan kepada mereka untuk mengatur diri sendiri, menentukan programprogramnya sendiri, termasuk budaya yang ingin dikuatkan. Hanya dengan penguatan budaya kerja melalui sekolah dan memberi kepercayaan kepada guru dan mitra untuk menginternalisasikan lewat aktivitas pembelajaran, nilai-nilai budaya kerja yang positif di sekolah dapat dibangun. 
Dengan model struktur kemitraan sekolah dengan DUDI yang terjadi di Finlandia, misalnya, akan banyak keuntungan yang dapat diambil, seperti: 1) menjamin ketersediaan tenaga kerja sesuai kebutuhan DUDI, 2) pihak DUDI menjadi lebih efisien karena tidak perlu lagi menyelenggarakan program pendidikan dan pelatihan bagi karyawannya, 3) DUDI dapat turut menyusun kurikulum pendidikan dan kejuruan yang tepat guna sesuai kebutuhan, 4) guru dan instruktur di SMK dapat memperoleh binaan dari DUDI sehingga kompetensi kerja dan budaya kerja yang dibangunnya sesuai harapan, dan 5) angkatan kerja yang disiapkan SMK benar-benar sesuai dengan kebutuhan pasar kerja.

Apabila paradigma tanggung jawab terstruktur tersebut berlangsung terus maka pada akhirnya akan menghasilkan kompetensi dan budaya kerja peserta didik yang baik. Hasil penelitian Dean dan Fornaciari (2013) selama lima tahun tentang struktur kursus dan rutinitas, menemukan bukti bahwa kinerja peserta didik yang sangat baik dapat dipupuk dengan menawarkan jenis struktur tertentu kepada mereka dengan cara-cara tertentu. Hal ini dapat dimaknai bahwa kompetensi dan budaya kerja peserta didik yang dibangun pada suatu waktu tertentu akan terjadi titik keseimbangan antara proporsi lulusan SMK dan kebutuhan DUDI. Apabila pergeseran tersebut telah mencapai titik keseimbangan, maka pada waktu berikutnya perubahan struktur ketenagakerjaan mulai berlangsung secara intensif dan mengarah pada struktur ekonomi. Pada titik inilah angka pengangguran lulusan SMK akan menurun.

Itulah tanggung jawab SMK sebenarnya, yaitu harus mendesain secara baik model pembelajaran baik teori maupun pola pemagangan di DUDI yang memberi ruang yang sebenarnya tentang rancangan kurikulum, iklim kerja, dan budaya kerja. Perolehan kompetensi dan budaya kerja sebenarnya inilah yang akan mengantarkan Iulusan SMK ini mampu berkompetisi di tingkat nasional maupun global. Pendekatan pembelajaran yang dijelaskan ini sekaligus juga mendorong internalisasi nilai lain, seperti etika dan akuntabilitas penghasil lulusan untuk perilaku bertanggung jawab yang sesuai dengan tujuan dan prinsip manajemen pendidikan kejuruan.

\section{SIMPULAN DAN SARAN}

\section{Simpulan}

Hasil pengkajian terkait dengan perancangan kurikulum SMK, diperoleh lima hal. Pertama, muatan nilai-nilai budaya kerja bagi peserta didik SMK penting. Kedua, pengembang kurikulum didorong untuk mengoreksi kembali pranata budaya kerja, yang mengarah pada nilai-nilai kerja keras, etos kerja, disiplin, tanggung jawab, kreativitas, kerja sama, moralitas, hingga standar etika dan estetika. Ketiga, pengembang kurikulum didorong untuk merumuskan ulang secara jelas esensi dari praktik kerja industri yang dilakukan peserta didik. Keempat, penumbuhan budaya kerja di sekolah dirancang dengan komitmen bersama melalui sistem, struktur, peraturan, dan praktik keseharian. Kelima, untuk penguatan budaya kerja bisa dilakukan melalui dua strategi, yaitu internalisasi nilai-nilai budaya kerja dan penciptaan lingkungan sekolah yang ramah dengan budaya kerja. Dari hasil kajian dapat disimpulkan bahwa perancangan kurikulum SMK harus membawa peserta didik mampu mentransformasikan pranata budaya kerja berbasis moral dan kinerja.

\section{Saran}

Berdasarkan simpulan yang di atas dapat disarankan beberapa hal. Pertama, para pemangku kepentingan pendidikan kejuruan hendaknya menyadari pentingnya budaya kerja sejak peserta didik memasuki SMK. Kedua, nilainilai budaya kerja hendaknya ditempatkan sebagai nilai utama dalam rancangan kurikulum SMK. Ketiga, pengembang kurikulum SMK hendaknya berperan strategis dalam 
menentukan muatan budaya kerja yang dapat diwujudkan bersama. Keempat, program praktik kejuruan, baik di sekolah maupun di DUDI hendaknya dijadikan proses transformasi budaya kerja secara positif. Kelima, guru dan kepala sekolah hendaknya merumuskan budaya kerja dengan bahasa lugas, jelas dan mudah dimengerti, bermakna tunggal sekaligus dengan frasa yang operasional untuk mempermudah guru mendesain pembelajaran.

\section{PUSTAKA ACUAN}

Aaltonen, K., Isacsson, A., Laukia, J., \& Vanhanen-Nuutinen, L. (2013). Practical skills, education and development- Vocational education and training in Finland. HAAGA-HELIA University of Applied Sciences.

Adhikary, P.K. (2005). Educational Reform For Linking Skills Development With Employment In Nepal. In M. Singh (Eds.), Meeting Basic Learning Needs in the Informal Sector Integrating Education and Training for Decent Work, Empowerment and Citizenship (pp. 215-228). Hamburg, Germany: UNESCO Institute for Education.

Agran, M., Hughes, C., Thoma, C. A., \& Scott, L. A. (2016). Employment Social Skills: What Skills Are Really Valued? Career Development and Transition for Exceptional Individuals, 39(2), 111-120. https://doi.org/10.1177/2165143414546741

Ashton, D. (2013). Cultural workers in-the-making. European Journal of Cultural Studies, 16(4), 468-488. https://doi.org/10.1177/1367549413484308

Asian Development Bank. (2014). Sustainable vocational training toward industrial upgrading and economic transformation: A knowledge sharing experience. Mandaluyong City, Philippines: Asian Development Bank.

Atchoarena, D. (2009). Overview: issues and options in financing technical and vocational education and training. InR. Maclean, D. Wilson, and C. Chinien (Eds.), International Handbook of Educationfor the Changing World of Work, Bridging Academic and Vocational Learning (pp.129-1036). Germany: Springer.

Badan Pusat Statistik. (2017). Berita Resmi Statistik No. 47/05/Th. XX, 05 Mei 2017. Jakarta: BPS.

Bauer, W \& Przygodda, K. (2003). New Learning Concepts within the German System of Vocational Education and Training. European Educational Research Journal, 2(1), 2240. First Published Mar 1, 2003.

Bendassolli, P. F. (2016). Work and culture: Approaching cultural and work psychology. Culture \& Psychology, 23(3), 372-390. First Published December 15, 2016 Research Article

https://doi.org/10.1177/1354067X16682939

Bendassolli, P. F., \& Tateo, L. (2018). The meaning of work and cultural psychology: Ideas for new directions. Culture \& Psychology, 24(2), 135-159. https://doi.org/10.1177/ $1354067 X 17729363$

Berbiglia, V.A. (2011). The Self-Care Deficit Nursing Theory as a Curriculum Conceptual Framework in Baccalaureate Education. Nursing Science Quarterly, 24(2),137-145. doi: 10.1177/0894318411399452.

Brodjonegoro, S. S. (2018). Kecakapan era 4.0, Harian Kompas, Rabu, 14 Februari 2018, hal. 6. 
Chapman, K. J., Meuter, M., Toy, D., \& Wright, L. (2006). Can't We Pick our Own Groups? The Influence of Group Selection Method on Group Dynamics and Outcomes. Journal of Management Education, 30(4), 557-569. https://doi.org/10.1177/1052562905284872

Clarke, L. \& Winch, C. (eds) (2007). Vocational Education: International approaches, development and systems. Routledge, Oxfordshire.

Dean, K. L. \& Fornaciari, C. J. (2013). Creating Masterpieces: How Course Structures and Routines Enable Student Performance. Journal of Management Education, 38(1), 10-42. First Published January 30, 2013.

Deissinger, T. (2015). The German dual vocational education and training system as 'good practice'? Local Economy, 30(5), 557-567. https://doi.org/10.1177/0269094215589311

Departemen Pendidikan dan Kebudayaan. (1996). Lima Puluh Tahun Perkembangan Pendidikan Indonesia. Jakarta: Depdikbud.

Doyle, L. (2012). Conceptualising a Transition: The Case of Vocational and Academic Learning in England, Scotland and the USA. Research in Comparative and International Education, 7(4), 446-464. https://doi.org/10.2304/rcie.2012.7.4.446.

Eichhorst, W., Rodríguez-Planas, N., Schmidl, R., \& Zimmermann, K. F. (2015). A Road Map to Vocational Education and Training in Industrialized Countries. ILR Review, 68(2), 314337. https://doi.org/10.1177/0019793914564963

Gale, T., Mills, C., \& Cross, R. (2017). Socially Inclusive Teaching: Belief, Design, Action as Pedagogic Work. Journal of Teacher Education, 68(3), 345-356. https://doi.org/10.1177/ 0022487116685754

Gondo, T. \& Dafuleya, G. (2010). Technical vocational education and training for microenterprise development in Ethiopia: a solution or part of the problem? Industry and Higher Education, 24(5), 381-392, First Published October 1, 2010.

Grabowska, I. (2017). Social skills, workplaces and social remittances: A case of post-accession migrants. Work, Employment and Society, 32(5), 868-886. First Published October 2, 2017 Research Article https://doi.org/10.1177/0950017017719840

Grugulis, I. dan Vincent, S. (2009). Whose skill is it anyway?: 'soft' skills and polarization, Work, Employment and Society, 23(4), 597-615. https://doi.org/10.1177/0950017009344862

Ha-Brookshire, J.E. \& Lee, Y. (2010). Korean apparel manufacturing industry: Exploration from the industry life cycle perspective. Clothing and Textiles Research Journal, 28(4) 279-294. https://doi.org/10.1177/0887302X10372958

Hiniker, L., \& Putnam, R.A. (2009) Partnering to Meet the Needs of a Changing Workplace. In: Maclean R., Wilson D. (eds) International Handbook of Education for the Changing World of Work. Springer, Dordrecht

Joo, J. (2007). The Impact of the Automobile and its Culture in the U.S., International Area Review, 10(1), 39-54. https://doi.org/10.1177/223386590701000103

Jones, M. E.,Cason, C. L. \& Bond, M. L. (2004). Cultural Attitudes, Knowledge, and Skills of a Health Workforce. Journal of Transcultural Nursing, 15(4), 283-290. , First Published Oct $1,2004$.

Kementerian Pendidikan dan Kebudayaan. (2011). Naskah Akademik Pengembangan Kurikulum. Tidak Dipublikasikan. Jakarta: Kemendikbud. 
Kementerian Pendidikan dan Kebudayaan. (2016). Data Pokok Pendidikan Dasar dan Menengah, Kementerian Pendidikan dan Kebudayaan. Oktober 2016. Direktorat Jenderal Pendidikan Dasar dan Menengah: Jakarta.

Kementerian Pendidikan dan Kebudayaan. (2017a). Materi Pelatihan Kurikulum 2013 Tahun 2017. Jakarta: Ditjen Dikdasmen.

Kementerian Pendidikan dan Kebudayaan. (2017b). Program Kerja Reformasi Birokrasi Kementerian Pendidikan dan Kebudayaan Tahun 2017. Jakarta: Kemendikbud.

Kementerian Pendidikan dan Kebudayaan. (2018). Peraturan Direktur Jenderal Pendidikan Dasar dan Menengah Nomor 06 tentang Spektrum Keahlian Sekolah Menengah Kejuruan (SMK)/ Madrasah Aliyah Kejuruan (MAK). Jakarta: Direktorat Jenderal Pendidikan Dasar dan Menengah.

King, K. \& Palmer, R. (2010). Plann-ing for technical and vocational skills development. Paris: UNESCO (United Nations Educational, Scientific and Cul-tural Organization).

Kiprianos, P., \& Christodoulou, M. (2015). Ambivalent Biographies in Adolescence: What Vocational Students Think and Feel About Their Schooling. SAGE Open. https://doi.org/ $10.1177 / 2158244015610795$

Kogan, I. \& Unt, M. (2008). The Role of Vocational Specificity of Educational Credentials for Labour Market Entry in Estonia and Slovenia. International Sociology, 23(3), 389-416. First Published May 1, 2008 Research Article https://doi.org/10.1177/0268580908088898

Kompas. (11 November 2017). Sumber daya manusia: belajar dari sekolah vokasi di Jerman. Hal. 18.

Kompas. (14 November 2017). Lulusan vokasi menganggur: kurikulum tak sesuai dengan kebutuhan Industri. Hal. 17.

Lizardo, O. (2017). Improving Cultural Analysis: Considering Personal Culture in its Declarative and Nondeclarative Modes. American Sociological Review, 82(1), 88-115. https://doi.org/ $10.1177 / 0003122416675175$

Malihah, E. (2015). An ideal Indonesian in an increasingly competitive world: Personal character and values required to realise a projected 2045 'Golden Indonesia'. Citizenship, Social and Economics Education, 14(2), 148-156. First Published August 12, 2015 Review Article. https://doi.org/10.1177/2047173415597143

Mendes, P., McCurdy, S., Allen-Kelly, K., Charikar, K., \& Incerti, K. (2015). Integrating professional social work identity and social justice advocacy: An analysis of the Australian campaign to restore Medicare rebates for accredited mental health social workers. Journal of Social Work, 15(5), 516-536. https://doi.org/10.1177/ 1468017314552050

Mendoza, K. S., \& McPherson, M. L. (2018). Knowledge, Skills, and Attitudes Regarding the Use of Medical Cannabis in the Hospice Population: An Educational Intervention. American Journal of Hospice and Palliative Medicine ${ }^{\circ}, 35(5)$, 759-766. https://doi.org/10.1177/ 1049909117738246

Ndraha, T. (2010). Budaya Organisasi, Cetakan Ketiga. Jakarta: Rineka Cipta. 
Newton, L. \& Kirk, H. (1999). The Relevance of Vocational Education for Occupational Therapy Support Workers. British Journal of Occupational Therapy, 62(3), 131-135. https:// doi.org/10.1177/030802269906200312.

Ngadi. (2014). Relevansi pendidikan kejuruan terhadap pasar kerja di Kota Salatiga. Jurnal Kependudukan Indonesia, 9(1), 59-70.

Ningsih, D.R. (2016). Potret Lulusan Sekolah Menengah Kejuruan (SMK) Program Keahlian Akuntansi dengan Dunia Kerja di SMK Negeri 1 Ngawi. Jurnal Kebijakan Pendidikan, 5(5), 573-547.

Raelin, J. A. (2008). Work-based learning. Bridging knowledge an action ini the workplace. New and revised Edition. San Francisco: John Wiley and Sons.

Republik Indonesia. (2016). Instruksi Presiden Republik Indonesia Nomor 9 Tahun 2016 tentang tentang Revitalisasi Sekolah Menengah Kejuruan dalam Rangka Peningkatan Kualitas dan Daya Saing Sumber Daya Manusia Indonesia. Jakarta: Kementerian Sekretariat Negara.

Rosen, R., Weiss, P. L., Zancanaro, M., \& Gal, E. (2017). Usability of a video modeling computer application for the vocational training of adolescents with autism spectrum disorder. British Journal of Occupational Therapy, 80(4), 208-215. https://doi.org/ $10.1177 / 0308022616680367$

Sahlberg, P. (2014). Finnish Lessons 2.0. What can the world learn from educational change in Finland? 2nd ed. New York, Teachers College, Columbia University.

Schütte, M. \& Spöttl, G. (2011). Development of Entry-Level Competence Tests: A Strategy for Evaluation of Vocational Education Training Systems. Research in Comparative and International Education, 6(3), 285-299. https://doi.org/10.2304/rcie.2011.6.3.285

Slamet PH. (2011). Peran Pendidikan Vokasi dalam Pembangunan Ekonomi. Cakrawala Pendidikan, Jurnal Ilmiah Pendidikan, XXX(2), 189-203.

Sonhadji, A. (2012). Manusia, Teknologi, dan Pendidikan Menuju Peradaban Baru. Malang: UM Press.

Stewart, D., \& Pepper, M. B. (2011). Close Encounters: Lessons From an Indigenous MBA Program. Journal of Management Education, 35(1), 66-83. https://doi.org/10.1177/ 1052562910384375

Thompson, E. R. (2003). A grounded approach to identifying national competitive advantage: a preliminary exploration. Environment and Planning A: Economy and Space, 35(4), 631657. https://doi.org/10.1068/a35110

Tran, L. T. (2013). Internationalisation of Vocational Education and Training: An Adapting Curve for Teachers and Learners. Journal of Studies in International Education, 17(4), 492507. https://doi.org/10.1177/1028315312469987

Trocchia, P. J., Swanson, D. L., \& Orlitzky, M. (2007). Digging Deeper: the Laddering Interview, a Tool for Surfacing Values. Journal of Management Education, 31(5), 713-729. https:// doi.org/10.1177/1052562906293611

Van den Broeck, A., De Cuyper, N., Luyckx, K., \& De Witte, H. (2012). Employees' job demandsresources profiles, burnout and work engagement: A person-centred examination. Economic and Industrial Democracy, 33(4), 691-706. https://doi.org/ $10.1177 / 0143831 \times 11428228$ 
Wallace, M., \& Leicht, K. T. (2004). Culture Wars in the Workplace?: Cultural Antecedents of Workers' Job Entitlement. Work and Occupations, 31(1), 3-37. https://doi.org/10.1177/ 0730888403259827

Warren, A. (2014). Working culture: The agency and employment experiences of nonunionized workers in the surfboard industry. Environment and Planning A. 46. 2300-2316. 10.1068/ a130330p.

Widarto, Sukir, Purnastuti, L. \& Wagiran. (2007). Peranan SMK kelompok teknologi terhadap pertumbuhan manufaktur. Jakarta: Direktorat Pembinaan Sekolah Menengah Kejuruan, Depdiknas. 